vician) strata. The occurrence of Ceratopea unguis in collection 11 may suggest a correlation of part of the middle member of the Wandel Valley Formation with the Smithville Formation of Arkansas and other Late Canadian equivalents of slightly younger age than the Cotter Formation. However, the position of collection 11 relative to other collections from the middle member of the Wandel Valley Formation is not known.

\title{
References
}

Billings, E. 1865: Palæozoic fossils, 1. Can. geol. Surv., Publ. 431, 426 pp.

Peel, J. S., Dawes, P. R. \& Troelsen, J. C. 1974: Notes on some Lower Palaeozoic to Tertiary faunas from eastern North Greenland. Rapp. Grønlands geol. Unders. 65, 18-23.

Troelsen, J. C. 1949: Contributions to the geology of the area round J $\phi$ rgen Bronlunds Fjord, Peary Land, North Greenland. Meddr Grønland 149,2, 29 pp.

Yochelson, E. L. 1973: The late Early Ordovician gastropod Ceratopea in the Arbuckle Mountains, Oklahoma. Oklahoma Geol. Notes 331, 67-78.

Yochelson, E. L. \& Barnett, S. J. 1972: The Early Ordovician gastropod Ceratopea in the Plattsburgh, New York area. J. Paleont. 461, 685-687.

Yochelson, E. L. \& Bridge, J. 1958: The Lower Ordovician gastropod Ceratopea. Prof. Pap. U.S. geol. Surv. 294-H, 281-302.

Yochelson, E. L. \& Copeland, M. J. 1974: Taphonomy and taxonomy of the Early Ordovician gastropod Ceratopea canadensis (Billings), 1865. Can. J. Earth Sci. 11, 189-207. Yochelson, E. L. \& Wise, O. A., Jr. 1972: A life association of shell and operculum in the Early Ordovician gastropod Ceratopea unguis. J. Paleont. 46, 681-684.

U. S. Geological Survey, Washington D.C., U.S.A.

\section{Beatricea from the Ordovician of Hall Land, North Greenland}

\begin{abstract}
John S. Peel
Large, somewhat irregular cylinders of the supposed stromatoporoid genus Beatricea Billings, 1857, have frequently been reported from Ordovician strata. Sokolov (1962) noted the occurrence of 14 species from the Urals, Siberia, Novaya Zemlya and North America, in addition to representatives of the closely related genera Aulacera Plummer, 1843 and Cryptophragmus Raymond, 1914. Although diverse Ordovician faunas were described from Greenland by Troedsson (1928), Poulsen (1927) and Teichert (1937), no record has previously been made of these genera in Greenland. It is therefore of some interest that specimens of Beatricea have now been identified in collections made by J. H. Allaart and P. R. Dawes in 1965 during 'Operation Grant Land' from Kap Ammen, on the northern coast of Hall Land, North Greenland.

The Hall Land specimens are referred to Beatricea regularis Stearn, 1956, originally described from the Upper Ordovician Stonewall Formation of southern Manitoba.
\end{abstract}


They occur in the lowest exposed unit of the Ordovician - ? Devonian section at Kap Ammen in association with Kochoceras, Armenoceras, Palaeofavosites, Catenipora, Maclurites and other gastropods. The fauna provides the first record of the Late Ordovician from the North Greenland fold belt.

Beatricea is unusual amongst stromatoporoids in that the coenosteum is not sheetlike or sphaeroidal but consists of cylinders which apparently grew upwards from the sea floor. The cylinders may be large - Twenhofel (1928) records an example $3 \mathrm{~m}$ long from Anticosti Island in the Gulf of St. Lawrence - although the Hall Land specimens are only fragments never exceeding $80 \mathrm{~mm}$ in length.

Beatricea regularis Stearn, 1956 (figs. 8a-f)

1956. Beatricea regularis Stearn, 1956, p. 53-54, Pl. X, fig. 14.

The coenosteum is known only from cylindrical fragments which attain a maximum length of about $80 \mathrm{~mm}$. The observed diameter of the slightly elliptical to subcircular cylinders varies between 25 and $40 \mathrm{~mm}$. The cylinders consist of a central column of large, thin-walled cysts surrounded in most specimens by a dense recrystallised zone, apparently formerly composed of small cysts of uniform size. In some specimens this cystose zone is surrounded by a very finely crystalline outer zone. In another case, an outer recrystallised zone is composed of large radially disposed calcite crystals. The cystose and outer zones may show an obscure concentric banding. In one specimen (fig. 8a) this banding is more strongly emphasised and semi-continuous cavities, now filled with fine sediment, are developed between the concentric cystose lamellae.

The size and shape of the single column of axial cysts appears uniform within any particular fragment. However, in two specimens (fig. $8 \mathrm{~b}$, c) the large cysts account for about two thirds of the total width of the colony, although elsewhere the relative width is reduced to between one third and a half. In cross-section, the central column may appear circular, elliptical or even reniform and may be central or excentric in its location. In some specimens the thin walls of the cysts in the central column have been subsequently broken and a coarsely crystalline infilling has developed.

Most of the specimens are weathered. However, the outer surface is seemingly generally smooth although one specimen exhibits a fine papillation. None of the specimens preserves the apical or basal termination of the cylinder, although a noticeable increase of width in one specimen suggests proximity to the base.

The Hall Land specimens differ from the type series described by Stearn (1956) only in their increased variability. This is manifested in the relative size of the axial cysts and in the nature of the enclosing finely cystose sheath. In particular, the tendency in MMH 13369 (fig. 8a) for cavities to develop between the concentric lamellae of the finely cystose medium is reminiscent of Cryptophragmus antiquatum Raymond, 1914. However, this Middle Ordovician species has well developed radial pillars whereas these structures have not been observed in either the Manitoban or Greenland specimens.

Bolton (1972) recently figured a specimen of Beatricea nodulosa Billings from the 


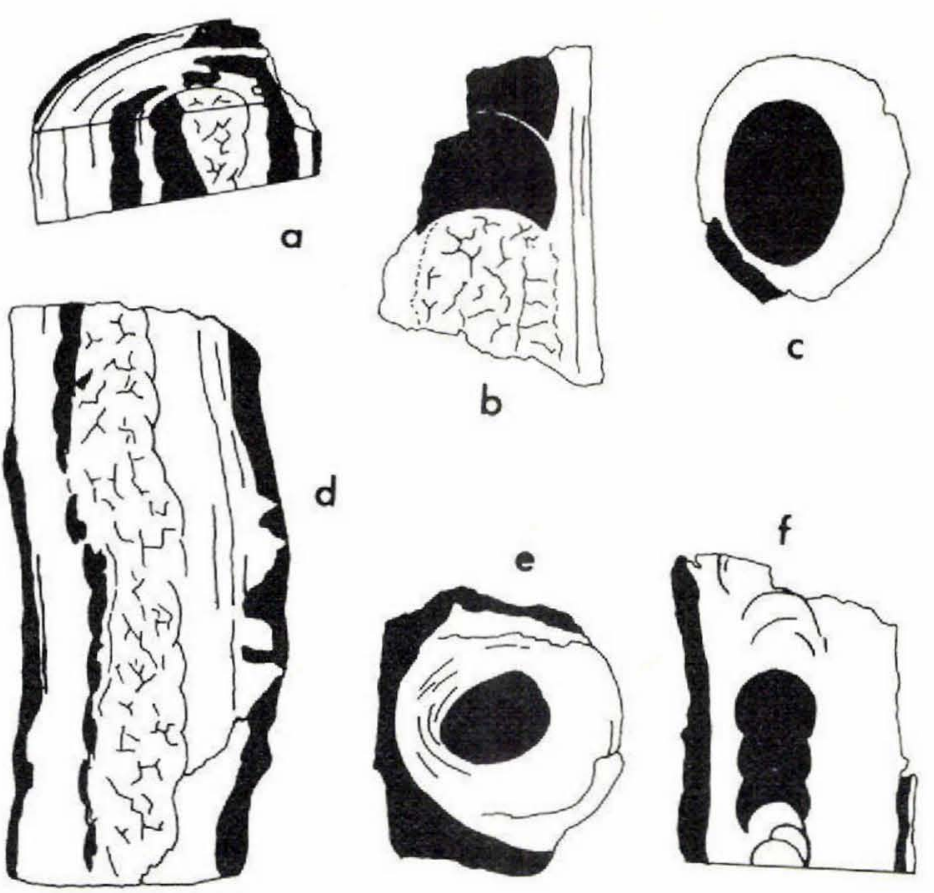

Fig. 8. Beatricea regularis Stearn, 1956, Kap Ammen, Hall Land, $\times 0.75$. a, MMH 13369 from GGU sample 82430, longitudinal and oblique transverse sections oriented with base upwards, $b$, MMH 13370 from GGU sample 82417. $c$, MMH 13371 from GGU sample 82433. $d$, MMH 13372 from GGU sample 82417. e, MMH 13373 from GGU sample 82433. $f$, MMH 13374 from GGU sample 82417. $b, d, f$ longitudinal sections; $c, e$ transverse sections.

Ellis Bay Formation (Upper Ordovician) of Anticosti Island, Canada, which closely resembles the Hall Land species. The specimen is not distinguishable from the currently illustrated specimens in terms of the size of the axial cysts and the width of the central column. However, the species is reportedly characterised by nodes on the outer surface in contrast to the smooth or finely papillate condition in Beatricea regularis.

\section{References}

Bolton, T. E. 1972: Geological map and notes on the Ordovician and Silurian litho- and biostratigraphy, Anticosti Island, Quebec. Pap. geol. Surv. Can. 71-19, 44 p.

Poulsen, C. 1927: The Cambrian, Ozarkian and Canadian faunas of Northwest Greenland. Meddr Gronland 70,2, 233-343.

Sokolov, B. S. 1962: Porifera, Archaeocyatha, Coelenterata, Vermes, In Orlov, Yu.A. (edit.) Fundamentals of paleontology 2. Izd. Akad. Nauk SSSR [Translated from Russian, 1971, Israel Program for Scientific Translations], $909 \mathrm{pp}$.

Stearn, C. W. 1956: Stratigraphy and palæontology of the Interlake Group and Stonewall Formation of southern Manitoba. Mem. geol. Surv. Can. 281, 162 pp. 
Teichert, C. 1937: A new Ordovician fauna from Washington Land, North Greenland. Meddr Gronland 119,1, 65 pp.

Troedsson, G. T. 1928: On the Middle and Upper Ordovician faunas of northern Greenland. Part II. Meddr Gr申nland 72(1),1, 197 pp.

Twenhofel, W. H. 1928: Geology of Anticosti Island. Mem. geol. Surv. Can. 154, 481 pp.

\section{Reconnaissance of the Thule Group and underlying basement rocks between Inglefield Bredning and Melville Bugt, western North Greenland}

\section{Peter R. Dawes}

Field work was undertaken in August and September using boat transport locally hired from Avatak Henson of Moriussaq and Innuterssuak Uvdloriak of Siorapaluk. Travel from Thule Air Base to headquarters at Thule at the end of July was by U.S. Coastguard icebreaker Westwind. The work was a southerly continuation of the coastal programme started in 1971 (Dawes, 1972). About $1000 \mathrm{~km}$ of coastline was traversed including Herbert $\varnothing$, Northumberland $\varnothing$, Haklyut $\varnothing$, Saunders $\varnothing$ and Wolstenholme $\emptyset$. Heavy ice conditions in mid-September prevented penetration into the fjords between Kap York and Savigsivik.

\section{Crystalline basement}

Two major rock complexes compose the basement south of Inglefield Bredning (fig. 9). The greater part of the region is made up of a gneiss-schist-granite complex which is bordered on the south by a suite of igneous rocks referred to here as the Kap York meta-igneous complex.

Gneiss-schist-granite complex. Severely deformed grey to pink, biotite and hornblendebearing veined gneisses of mainly granodioritic composition form the dominant rock types. These gneisses are commonly melanocratic and characterised by reddish brown weathering. Numerous amphibolite layers, schlieren and concordant quartzo-feldspathic veins and streaks produce transitions to banded and streaky gneisses. Local areas of porphyroblastic gneiss and foliated granitoid rocks were seen along the coast between Narssârssuk and Parker Snow Bugt and are probably comparable in type with the extensive area of 'porphyroblastic gray gneiss' described by Davies et al. (1963) near the Inland Ice south of Pitugfik Gletscher. A mass of medium-grained leucocratic granite on the north side of Pitugfik Gletscher lies in sharp contact with gneisses and amphibolites and is probably of intrusive origin.

Biotite-garnet schists, mica-chlorite-talc schists and quartz-mica schists form small concordant units in the gneiss terrain. Tracts of quartz-rich garnet gneiss in the interior of Olrik Fjord are probably of metasedimentary origin. 